\title{
Jejunum and Ileum Neuroendocrine Tumor Pathologic TNM Finding v8
}

National Cancer Institute

\section{Source}

National Cancer Institute. Jejunum and Ileum Neuroendocrine Tumor Pathologic TNM

Finding v8. NCI Thesaurus. Code C135101.

A pathologic finding about one or more characteristics of a jejunum and ileum

neuroendocrine tumor, following the rules of the TNM AJCC V8 classification system. 